Araştırma / Research

\title{
Rüzgar Enerjisinin Önemli Geçiş Yerlerinden Olan Çanakkale Bölgesindeki Bazı Rüzgar Enerji Santralleri için Kapasite Faktörü İncelemesi
}

\author{
Halil Gençel $^{1,2} *$ İsmail Tarhan ${ }^{2,3}$ \\ ${ }^{1}$ Enerjisa Çanakkale RES Mahmudiye Ezine /Çanakkale \\ ${ }^{2}$ Çanakkale Onsekiz Mart Üniversitesi Fen Bilimleri Enstitüsü Enerji Kaynakları ve Yönetimi ABD \\ ${ }^{3}$ Çanakkale Onsekiz Mart Üniversitesi, Enerji Kaynakları Araştırma ve Uygulama Merkezi (ÇEKAM)
}

08.03.2019 Geliş/Received, 15.04.2019 Kabul/Accepted

\section{Özet}

Son yıllarda hızla artan enerji tüketiminin karşılanabilmesi için konvansiyonel enerji kaynakları daha fazla kullanılmak zorunda kalınmıştır. Bunun sonucu olarak ortaya çıkan bazı çevresel sorunlar daha fazla kendini hissettirmiştir. Dolayısı ile temiz, yenilenebilir, ekonomik ve çevre dostu alternatif enerji kaynaklarına ilgi artmıştır. Bu bağlamda; Çanakkale ili yenilenebilir enerji kaynaklarından, özellikle rüzgar enerjisi potansiyeli bakımından, oldukça verimli bir konumdadır. Rüzgar enerji santrallerinin gerek yer seçimi gerekse santrallerin enerji üretim verimi, emre amadelik (availability) gibi önemli parametreleri ortaya koymada kapasite faktörü önemli rol oynamaktadır. Kurulacak santral tipinin de seçiminde önemli rol oynayan kapasite faktörü, santralin belirli bir periyotta ürettiğgi enerjinin santral tam kapasite ile çalıştığında üreteceği enerjiye oranı olarak tanımlanır. Öte yandan kapasite faktörü, enerji kaynağı yanında santralin tasarımı, meteorolojik koşullar, planlı ve plansız teknik bakım süreçlerinin sıklı̆̆ı, üretime ara verme gibi bazı etkilere bağlı olarak değişir. Bu çalışmada; Çanakkale ili sınırları içerisinde kurulu olan bir rüzgar enerji santralinin kapasite faktörlerinin araştırılması, elde edilecek verilerin karşılaştırılarak incelenmesi, sonuçların irdelenmesi ve yorumlanması hedeflenmektedir.

Anahtar Kelimeler: kapasite faktörü, rüzgar enerji santrali (RES), yenilenebilir enerji, pürüzlülük, weibull ve rayleigh dağılımları, emre amadelik.

\section{Capacity Factor Analysis for Some Wind Power Plants in the Çanakkale Region, One of the Important Transition Areas of Wind Energy}

\begin{abstract}
In recent years, in order to meet the rapidly increasing energy consumption, conventional energy sources have to be used more. Therefore, the interest in the clean, renewable, economic and environmental-friendly alternative energy sources has increased. In this context, Çanakkale province has very important position in terms of renewable energy sources, especially the wind energy potential. The capacity factor plays an important role in the determination of the important parameters of wind power plants such as the location selection and energy production efficiency. The capacity factor, which plays an important role in the selection of the type of power plant to be established, is defined as the ratio of the energy produced by the power plant in a certain period to
\end{abstract}


the energy that will be produced when the plant is operating at full capacity. Besides the capacity factor and energy source, the design of the power plant, meteorological conditions, the frequency of planned and unplanned technical maintenance processes, depending on some effects (e.g. pausing the production) are also important. In this study; it is aimed to investigate the capacity factors of a wind power plant in Çanakkale, compare the obtained data, and examine and interpret the results.

Keywords: capacity factor, wind power plant (WPP), renewable energy, roughness, weibull and rayleigh distributions, availability.

\section{Giriș}

Yenilenebilir enerji üzerine çeşitli tanımlar olmakla birlikte en yalın ifadesiyle, doğal süreçle- ri devam eden, sürekliliği olan, ikincil enerjiye dönüşümü ile bitmeyen, yenilenerek akışı de- vam eden enerji türüdür. İnsanlığın enerjiye ihtiyaç duyduğu dönemden günümüze enerji gereksinimleri büyük ölçüde kömür, petrol, doğalgaz gibi fosil yakıtlar ve bunlardan elde edilen elektrik üretimi yoluyla karşılanmaktadır. Günümüzde enerji kaynağı olarak çoğunlukla kullanılan petrol, kömür, doğal gaz gibi fosil yakıtların kısıtlı olması yanında sera etkisi başta olmak üzere olumsuz çevre etkileri göz önüne alındığında, özellikle son yıllarda rüzgar, gü- neş, biyokütle, jeotermal gibi yenilenebilir enerji çalışmaları hız kazanmış ve bu doğrultuda teknolojik araştırmalara ağırlık verilmiştir. Rüzgar enerji santrallerinin kurulumlarına yönelik teknoekonomik bir değerlendirme Gökçek ve ark. (2007) tarafından yapılmıştır. Rüzgar tür- binlerine ait türbin sınıfı ile kapasite faktörü ilişkisi Çetin ve ark. (2011) tarafından incelen- miştir. Türkiye'nin çeşitli il ve bölgelerinin rüzgar enerji potansiyelleri üzerine çalışmalar özellikle 2000 yılından sonra ağırlık kazanmıştır (Köse ve ark., 2004; Bilgili ve ark., 2004; Akpınar ve Akpınar, 2004; Özdamar ve ark., 2005; Eskin ve ark., (2008); Güler, 2009; Uçar ve Balo, 2009; Araslan, 2010). Rüzgar, güneş, su gibi sürdürülebilir ve doğa dostu temiz ener- ji kaynakları yenilenebilir enerji kaynakları olarak adlandırılır ve bu doğal enerji kaynaklarına,

$\begin{array}{ll}\text { - } & \text { Akıntı Enerjisi } \\ \text { - } & \text { Biyo-kütle Enerjisi } \\ \text { - } & \text { Dalga Enerjisi } \\ \text { - } & \text { Hüneş Enerjisi } \\ \text { - } & \text { Hidroelektrik Enerji } \\ \text { - } & \text { Heotermal Enerji } \\ \text { - } & \text { Rüzgar Enerjisi }\end{array}$

gibi alternatif enerji kaynakları örnek olarak verilebilir.

Rüzgar enerjisi ve teknolojileri üzerine yapılan çeşitli çalışmalar (Güler, 2009; Uçar ve Balo, 2009; Araslan, 2010) sonucu elde edilen gelişmeler, rüzgar enerjisinden elektrik üretiminin avantajlarının ortaya konması yanında rüzgar enerjisi santrallerinin yaygınlaşmasına, yatırımların ve tesis kurulumlarının artmasına önemli katkılar sağlamıştır. Bu bağlamda; rüzgar enerji potansiyeli bakımından Çanakkale bölgesi ulusal ve uluslararası yatırımcılar açısından cazip 
bölgeler arasında yerini almaktadır ve son yıllarda bölgede büyük rüzgar santral yatırımları yapılmaktadır. $\mathrm{Bu}$ yatırımlar; milli hedefler ve ulusal beklentilerin belirtildiği kalkınma programlarında da sıkça vurgulanmaktadır. Türkiye'de enerji yatırımları ve destekleme mekanizmala- rında yapılan iyileştirmeler, desteklerin ve teşviklerin önünün açılması sonucu rüzgar, güneş, biyokütle gibi doğa dostu yenilenebilir enerji kaynaklarından daha fazla yararlanılmasının önü açılmıştır. Bu tür çalışmalar ve girişimler hem ekonomik hem de stratejik anlamda dış ba- ğımlılığın baskısının azaltılmasında önemli rol oynamaktadır.

Kurulacak olan rüzgar enerji santrallerinin verimli olarak işletilmesinde belli başlı kriterlerden olan kapasite faktörünün ve teknik enerji potansiyelinin araştırılması ve irdelenmesi önemli- dir.

Ülkemizin rüzgar teknik enerji potansiyeli açısından oldukça iyi konumda olan bölgelerinden biri de Çanakkale ilinin yer aldığı güney Marmara bölgesidir. Bu durum rüzgardan elektrik enerjisi üretimi yapan sahaların kurulması ve bu sahaların en iyi şekilde değerlendirilmesi açışından Çanakkale ilini ön sıralara çıkartmaktadır.

Rüzgar elektrik üretim santrallerinde enerji hammaddesi olan rüzgar, ekseriyetle stabil esmemekte ve türbin yatırım maliyetleri nispeten yüksek olmaktadır. $\mathrm{Bu}$ ve benzeri sorunlar nedeni ile rüzgar santrali kurulacak sahaların, kurulum öncesinde sahanın teknik potansiyeli, sahanın kapasite faktör değişim analizleri, rüzgar yön değişim ve şiddetleri önemli rol oynamaktadır. Dolayısıyla sahanın kapasitesine ve rüzgar rejim değişikliğine göre, türbin sınıflarının belirlenmesi, türbin çevirme kapasitesi faktörlerinin belirlenmesine yönelik ön araştırmaların ve değerlendirmelerin titizlikle yapılması çok önem taşımaktadır.

Bu çalışmada; örnek olarak seçilen saha için rüzgar türbinlerinin yıllık enerji üretimleri, rüz- gar hızı değerleri, hakim rüzgar yönü, verimleri gibi verilerden yararlanarak sahanın kapasite faktörünün belirlenmesi yanında, türbin çevirme oranları, Betz limiti ile bağıl verim değerleri ve kapasite faktörünün değişimini etkileyen sebeplerin irdelenmesi ve araştırılması amaçlan- mıştır. Bu çalışma ile Çanakkale'nin rüzgar enerjisi kapasite faktörünün belirlenmesi üzerine yapılmış az sayıda çalışmalara katkı sağlanmış olacaktır.

\section{Materyal ve Yöntem}

\subsection{Sahanın Kurulmasındaki Kapasite Faktörü Yeterliliği}

Kapasite faktörü (KF); sahanın teknik enerji kapasitesi ve kurulu olan veya kurulacak santralın, ayda veya yıllık bazda ürettiği elektrik enerjisinin, ayda veya yılda, nominal kurulu güçte üretebilecek kapasiteye bölünmesi ile elde edilen bir yüzdelik sayısıdır. Rüzgar Enerji Santral (RES) sahalarının kurulmasına izin veren Enerji Bakanlığı, sahanın kapasite faktörünün \%25'ten büyük (KF > 0,25) olmasını istemektedir. Türkiye'deki rüzgar santralleri için kapasite faktörleri ayrıntıları ile Şenkal ve Çetin (2009) ve Çetin (2010) tarafından ele alınmış ve irdelenmiştir.

\subsection{Araştırma Sahası}

$\mathrm{Bu}$ çalışmada; Çanakkale ilinin Güney Bölgesi'ndeki bazı rüzgar enerji sahalarının teknik potansiyeline bakılmış, Çanakkale Güney Bölgesi teknik kapasite faktörü ve kurulu RES kapasite faktörleri üzerinde yoğunlaşılmıştır. Kapasite faktörlerindeki değişime sebep olan ve dolayısı ile enerji verimliliğine etki eden olası sebepler ve veriler toplanarak irdelenmiştir. 


\subsection{Araştırma Verileri}

Çalışmada Çanakkale iline ait meteoroloji verileri yanında santral verilerinden de yararlanılmış olup, Şekil 2.1'de (X) ile belirtilen örnek santral (39.873161 K enlem ve 26.237844 D boylam) elektrik enerjisi üretim verileri toplanmış, türbin çevirme kapasitelerine ve santralin kapasite faktörü çıkartılarak çevirme faktörlerinde ve kapasite faktöründeki artışa sebep olan etkenler incelenmiştir. Türbin verimi ve bağıl verim bilgileri, gerçek verilere istinaden elde edilerek, olası etkiler ve sebepler irdelenmiştir.

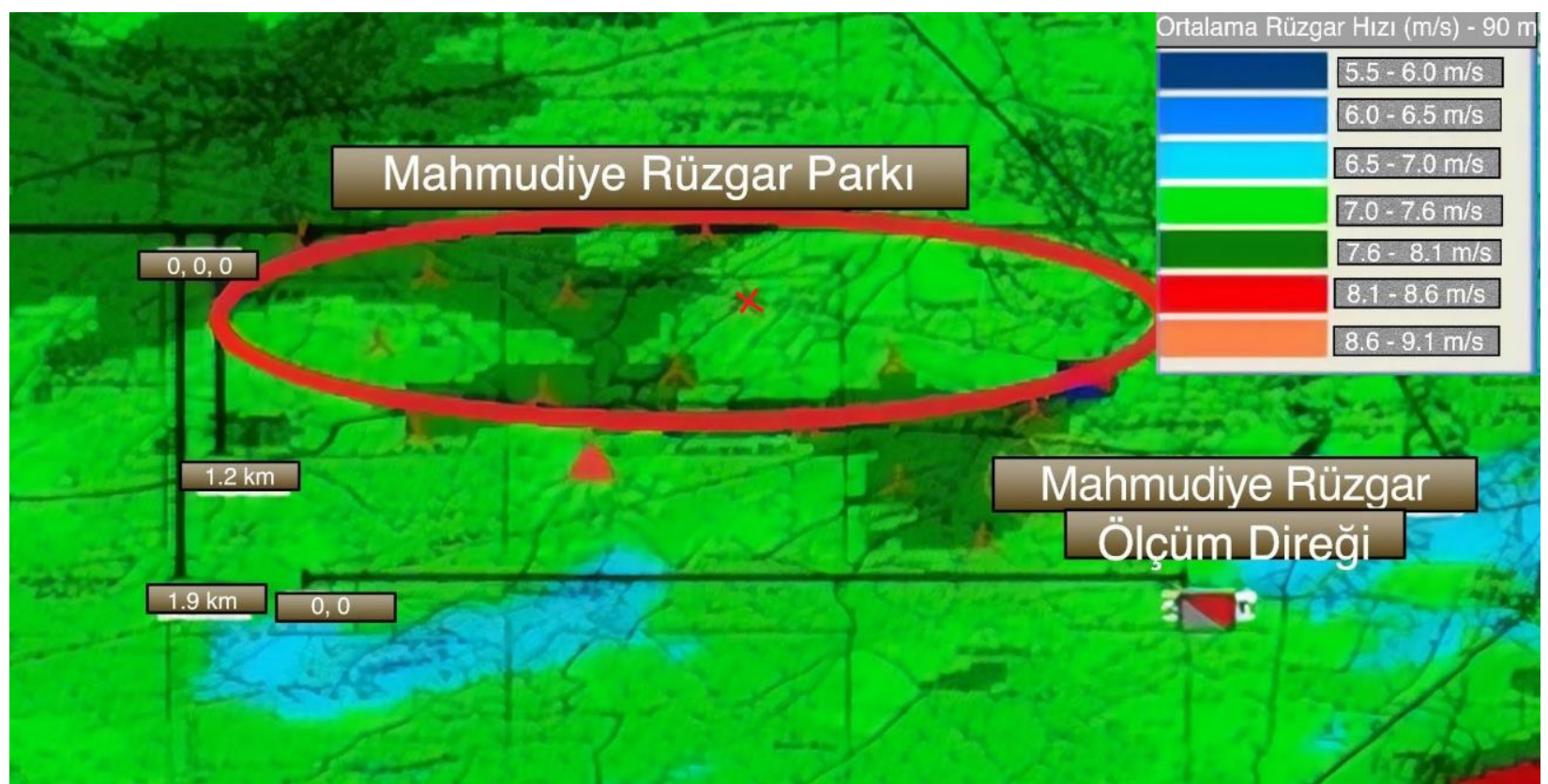

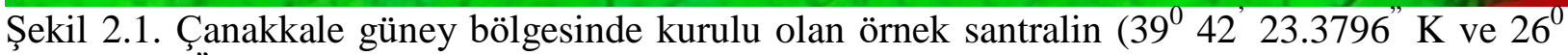
14 ' 16.2384" D) yerleşim yerini ( $\mathbf{X}$ ile işaretlenen) ve rüzgar potansiyelini gösteren konum haritas1

\section{4. Çanakkale Bölgesindeki Enerji Santralleri}

Çanakkale bölgesinde kurulu enerji santralleri yakıt cinsine ve kurulu güçlerine göre sınıflandırılması Çizelge 2.1 de listelenmiştir.

Çizelge 2.1. Çanakkale bölgesi yakıt cinsine göre toplam kurulu güç (Şenlik ve ark., 2018)

\begin{tabular}{|l|c|c|}
\hline Yakıt cinsine göre santraller & Toplam kurulu güç (MW) & Yüzdesi (\%) \\
\hline Kömür santralleri & $3.245,0$ & 89,48 \\
\hline Rüzgar santralleri & 299,8 & 8,27 \\
\hline Doğal gaz santralleri & 21,6 & 0,60 \\
\hline Jeotermal santralleri & 15,5 & 0,43 \\
\hline Biyogaz santralleri & 15,2 & 0,42 \\
\hline Atık 1S1 santralleri & 15,0 & 0,41 \\
\hline Hidrolik santralleri & 13,09 & 0,36 \\
\hline Güneş santralleri & 1,18 & 0,03 \\
\hline Toplam & 3.626 & 100 \\
\hline
\end{tabular}

Çizelge 2.1'den de görüleceği üzere elektrik üretimine yönelik santrallerinin toplam kurulu gücü 3.626 MW'dır ve Çanakkale ilinde kurulu enerji santrallerinin yaklaşık \% 90'ının kömüre dayalı termik santrallerinden oluşmaktadır (Anonim, 2019a). Termik santrali 
yaklaşık 300 MW kurulu güç ile \% 8,3 paya sahip (Anonim, 2019bc) olan ve yenilenebilir enerji kaynakları arasında üst sıralarda yer alan rüzgar santralleri takip etmektedir (Şekil 2.2).

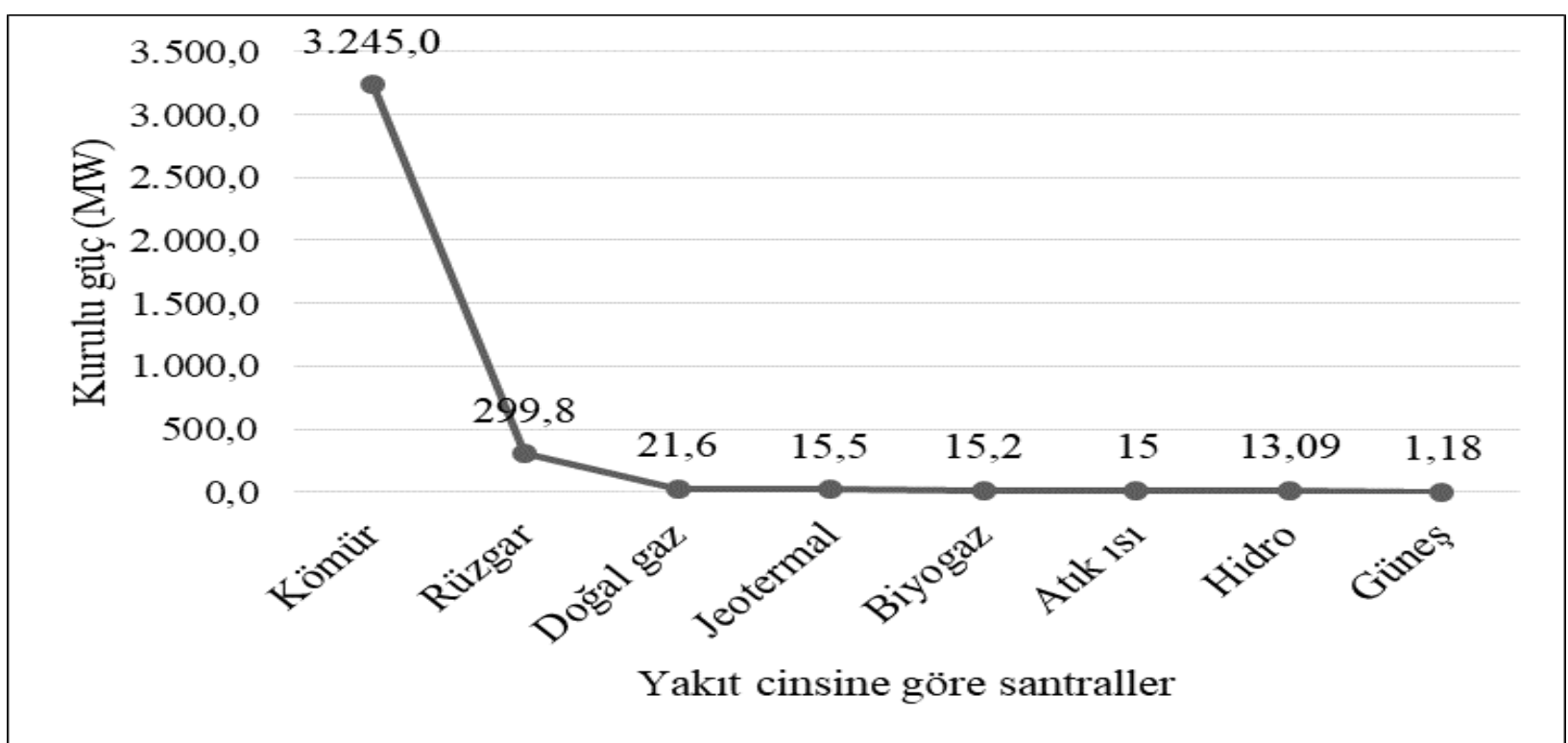

Şekil 2.2. Çanakkale bölgesi yakıt cinsine göre kurulu güç grafiği

\subsection{Türkiye Rüzgar Enerji Potansiyeli}

Ülkemizin Rüzgar Enerji potansiyeli haritasına (Şekil 2.3) baktığımızda Çanakkale, Balıkesir ve İzmir bölgeleri rüzgar enerjisi potansiyeli açısından ilk sıralarda yer almaktadır. Bunu Ege ve Akdeniz kıyıları ile Trakya ve İç Anadolu izlemektedir (Anonim, 2019d).

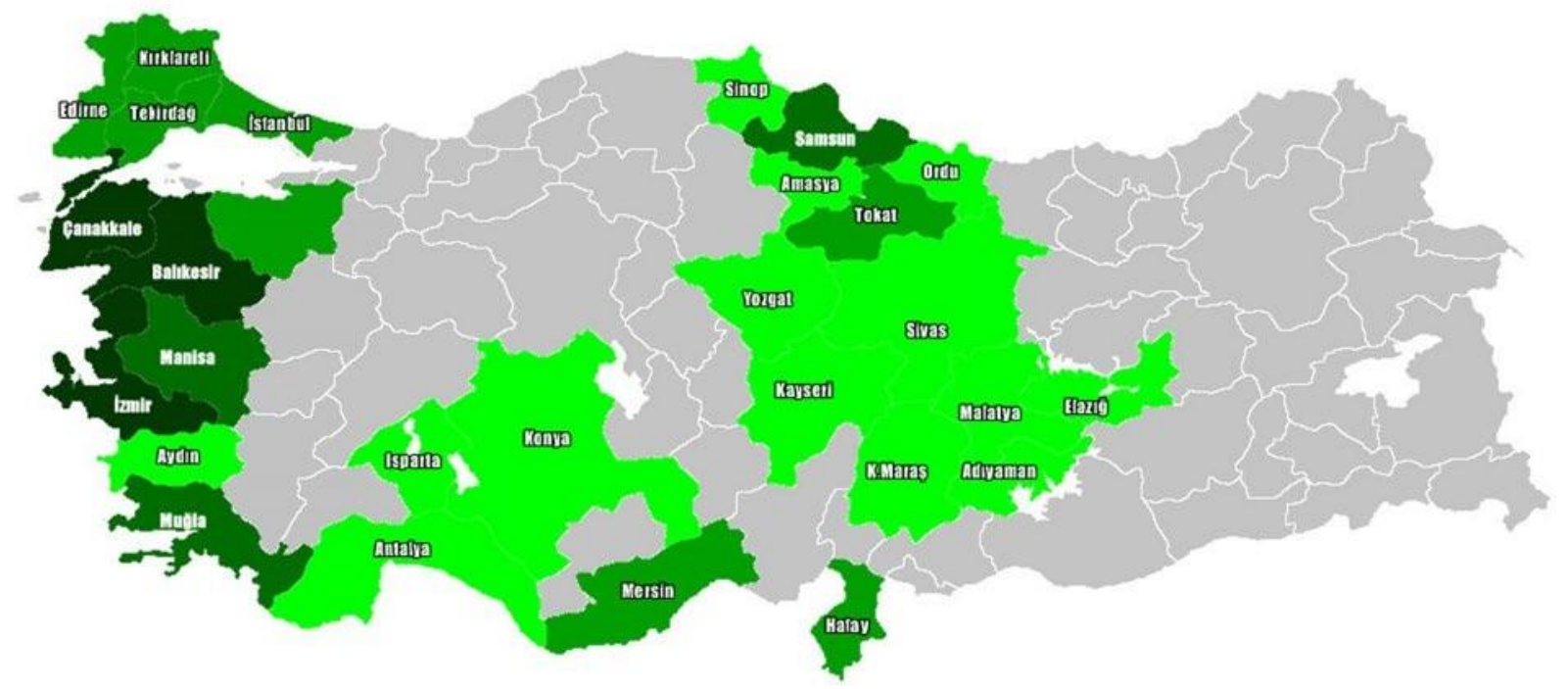

Şekil 2.3. Türkiye rüzgar enerji potansiyeli haritası (Anonim, 2019d) 


\section{6. Çanakkale Bölgesi Kurulu Elektrik Üretim Santralleri}

Çanakkale bölgesinde kömür, linyit doğal gaz gibi fosil yakıt kaynaklı santraller yanında rüzgar, güneş, hidroelektrik, jeotermal gibi yenilenebilir enerji kaynaklarına dayalı elektrik üretim santralleri de aktif olarak yer almaktadır. Çanakkale bölgesinde kurulu ve aktif üretim yapan elektrik enerjisi üretim santralleri, firma, tesis ve kurulu güçleri Çizelge 2.2'de listelenmiştir.

Çizelge 2.2. Çanakkale bölgesi elektrik santralleri (Anonim, 2019a'dan uyarlanmıştır)

\begin{tabular}{|c|c|c|c|c|}
\hline No & Santral Ad 1 & Firma & Tesis & $\begin{array}{l}\text { Kurulu Güç } \\
\text { (MW) }\end{array}$ \\
\hline 1 & Termik Santralı Kara Biga & Alarko Enerji & İthal Kömür & 1.320 \\
\hline 2 & İÇDAŞ Termik Santralı Bekirli & İÇDAŞ Elektrik & İthal Kömür & 1.200 \\
\hline 3 & İÇDAŞ Termik Santralı Biga & İÇDAŞ Elektrik & İthal Kömür & 405 \\
\hline 4 & 18 mart Termik Santralı Çan & EÜAŞ & Linyit & 320 \\
\hline 5 & İÇDAŞ Biga RES & İÇDAŞ Enerji & Rüzgar & 60 \\
\hline 6 & İntepe RES & Demirer Enerji & Rüzgar & 56 \\
\hline 7 & Koru Rüzgar Santralı & Borusan Enerji & Rüzgar & 50 \\
\hline 8 & Çamseki RES & Demirer Enerji & Rüzgar & 44 \\
\hline 9 & Çanakakle Rüzgar Santralı & Enerjisa Üretim & Rüzgar & 30 \\
\hline 10 & Sares Rüzgar Santralı & Gama Enerji & Rüzgar & 28 \\
\hline 11 & Çanak. Seramik D.Gaz Santralı & Çanakkale Seramik & Doğal Gaz & 22 \\
\hline 12 & Akçansa Çimento Atık Isı & Akçansa & At1k Is1 & 15 \\
\hline 13 & Burgaz Rüzgar Santralı & Polat Enerji & Rüzgar & 15 \\
\hline 14 & Gönen HES & EÜAŞ & Hidro Elektrik & 11 \\
\hline 15 & Bores Rüzgar Santralı & Demirer Enerji & Rüzgar & 10 \\
\hline 16 & Babadere Jeotermal Santralı & MNT Enerji & Jeotermal & 8 \\
\hline 17 & Tuzla jeotermal Santralı & Enda Enerji & Jeotermal & 7,5 \\
\hline 18 & Ayres Rüzgar Santralı & Notos Elektrik & Rüzgar & 5 \\
\hline 19 & Karamendre HES & Berrak Su Enerji & Hidro Elektrik & 2,49 \\
\hline 20 & Meriç Güneş Enerji Santralı & Fatma Deniz Meriç & Güneş & 1 \\
\hline 21 & Gökçe RES & & Rüzgar & 0,9 \\
\hline 22 & Çahan RES & & Rüzgar & 0,9 \\
\hline 23 & Kıvam Gida RES & & Rüzgar & 0,5 \\
\hline 24 & Papağan Gıda Güneş Santralı & Papağan Gıda & Güneş & 0,18 \\
\hline
\end{tabular}

Çanakkale bölgesindeki elektrik üretim santrallerinin kurulu güçlerine bakıldığında $3.626 \mathrm{MW}$ değeri ile Çanakkale bölgesi elektrik üretim kapasitesi açısından Türkiye'nin kurulu gücüne yaklaşık \%5 civarında katkı sağlamaktadır. Çanakkale bölgesinde $50 \mathrm{~m}$ rüzgar ölçümlerinin ortalama değeri $7 \mathrm{~m} / \mathrm{s}$ ve kapasite faktörünün de \%35 civarında olması Çanakkale bölgesinin rüzgar enerji yatırımlarında ekonomik değer taşıdı̆̆ı ve bu yönüyle rüzgar enerjisinde lider iller arasında üst sıralarda yer aldığı söylenebilir (Anonim, 2019c). 


\section{Bulgular ve Tartışma}

\subsection{Kapasite Faktörü Analizi}

Kaynağı sonlu ve kıt olan fosil yakıtların hızla tüketilmesi ve çevreye olan olumsuz etkilerinden dolayı yenilenebilir enerji kaynaklarından olan rüzgar enerjisinden elektrik üretilmesi çalışmaları ülkemiz ve Dünyada büyük önem taşımakta, yenilenebilir enerji teknolojileri üzerine gelişmeler ve bilimsel araştırmalar gittikçe önem kazanmaktadır. Milli hedefler ve ulusal beklentiler çerçevesinde Türkiye enerji yatırımları vizyonunda stratejik öneme sahip olan ve desteklenmesi öncelikli olarak programlara dahil edilen rüzgar enerji santralleri kurulacak sahalarda aranan belli başlı kriterlerden teknik potansiyel ve kapasite faktörlerinin araştırılması bu açıdan oldukça önemlidir.

Ülkemizde rüzgar teknik potansiyeli oldukça iyi olan bölgelerden biri de Çanakkale ili olup, bölgede rüzgar enerjisi üretimine yönelik yatırımlar önemli oranda artış göstermekte, ulusal ve uluslararası ortaklı yatırımlar artarak devam etmektedir. Rüzgar yatırım maliyetlerinin nispeten yüksek olması yanında enerji üretim ham maddesi olan rüzgar enerjisinin stabil olmaması ve sürekli esmemesi gibi sorunlar nedeniyle, santral sahalarının kurulmadan önce bazı ön araştırmaların yapılması büyük önem arz etmektedir.

Yatırımcılar ve ülkemiz için önemli yeri olan yenilenebilir enerji kaynaklarından elektrik üretilmesine yönelik santrallerin kurulmasında bazı kriterlerin iyi araştırılıp analiz edilmesi gerekmektedir. Bunlardan en önemlileri; rüzgarın enerji teknik potansiyeli, teknik kapasite faktörü, türbin sınıflarının belirlenmesi, kurulacak olan santral sahasının ve türbinlerin, çevirme ve kapasite faktörünün belirlenmesidir.

\subsection{RES Santrallerinin Kapasite Faktörünün Belirlenmesi}

Kapasite faktörü; bir enerji üretim santralinin bir y1l $(365 \times 24=8760$ saat $)$ içerisinde kurulu gücünün ne kadarını kullanarak enerji ürettiğini veya üretebileceğini ifade eder (Mathew, 2006; Şenkal ve Çetin, 2009). Bir başka ifadeyle, çeşitli kaynaklarda da (Akkaş, 2001) ifade edildiği gibi, bir rüzgar türbininin belirlenen bir periyotta üretmiş olduğu enerjinin, türbinin nominal güçte çalışmasıyla periyot süresince üretebileceği toplam enerjiye oranı kapasite faktörü olarak adlandırılır. Kapasite faktörü:

$$
K F=\frac{Y i l d a \text { Üretilen Toplam Enerji Miktarl }}{\text { Türbinin Nominal Güçte Yilda Üretmesi Gereken Enerji Miktarı }}
$$

olarak ifade edilmektedir (Akkaş, 2001). Literatürde $C_{p}$ olarak da verilen kapasite faktörü (KF) teorik olarak 0-100 arası değerler alabilir, ancak bu değer pratikte 20-70 arasında gözlenmektedir (Anonim 2019e). Rüzgar santralleri, çeşitli kaynaklarda da vurgulandığı gibi, yatırımlar öncesinde gerçekleştirilen ön çalışmalarda önemli yer tutan fizibilite çalışmaları, var olan kaynağın en optimum biçimde irdelenmesi ve değerlendirilmesi sonucu isabetli finansal ve teknik modellerin kurulabilmesinde oldukça önem taşır (Ay, 2016). Bu tür çalışmalarda, rüzgar türbinlerinde enerji üretimini dikkate değer oranda etkileyen çeşitli parametrelerin olduğu, bu parametrelerin değişik sahalarda farklı değerler alabileceği ve bu nedenle, seçilen türbinlerin performans analizlerinin her bir türbin sahası için ayrıca irdelenerek değerlendirilmesi gerektiği vurgulanmaktadır.

Örneğin herhangi bir marka türbin, bir bölgede çok iyi kapasite kullanımı yaparken, diğer bölgede 
aynı verimi göstermeyebilir. Çetin ve ark (2011) tarafından da dikkat çekildiği gibi, rüzgar türbinlerinin teknik performansları ile birlikte teknik özellikleri de göz önüne alındığında, rüzgar santrallerin kapasite faktörlerinin rüzgar hızının, dolayısı ile potansiyelinin yüksek olduğu sahalardan doğrudan etkilendiğinin gözlendiği belirtilmektedir. Ayrıca; bu tür hesaplamalar ve modellemelerin birlikte yapılması, türbin yatırımcılarının daha kısa sürede yatırımlarını amorti etmelerine yol açar. Öte yandan; üreticiler ile birlikte kullanıcıların türbine ait kapasite faktörüne dair doğru bilgilere sahip olmaları bilinmesi gereken önemli bir performans göstergesidir (Çetin ve ark., 2011).

Akkaş (2001)'a göre, kurulması planlanan yada kurulmuş bir rüzgar enerji santralinin gerek teknik ve gerekse ekonomik anlamda uygulanabilirliği yanında sürdürülebilirliğinde de kapasite faktörü bir parametredir.

Uygun bir yerin seçimi için, kullanılacak türbine ve sahaya ait kapasite faktörüne öncelikle bakılır. Ancak kapasite faktörünün düşük olup da, elektrik enerji üretiminin yüksek olduğu durumlarında nadiren de olsa varlığı unutulmamalıdır. Bu durum, daha güçlü kapasitede türbin kullanımı ve nominal güç değeri ile açıklanabilir. Kurulması planlanan sahanın enerji teknik potansiyeli kapasiteleri hesaplanarak, bu sahada hangi sınıf türbin secimi yapılacağına karar verilmesi ve bölgenin saha kapasite faktörlerine bakılarak yatırım hesaplamalarının yapılması gereklidir (Çetin ve ark., 2011).

\section{3. Çanakkale Güney Bölgesi Seçilen Santral ve Türbin Özellikleri}

\subsubsection{Santral Özellikleri}

Çanakkale'nin güney bölgesi Ezine ilçesi, Mahmudiye yerleşkesinde bulunan santral ve özellikleri bu çalışmada örnek santral olarak ele alınmıştır. Seçilen rüzgar enerji santralini karakterize eden temel parametreler aşağıda verilmektedir.

$\begin{array}{ll}\text { Kurulu Güç } & : 29,90 \mathrm{MWe} \\ \text { Y1llık Elektrik Üretimi } & : 81 \mathrm{GWh} \\ \text { Türbin Adedi } & 13 \\ \text { Rüzgar Santral Yeri } & : \text { Ezine }\end{array}$

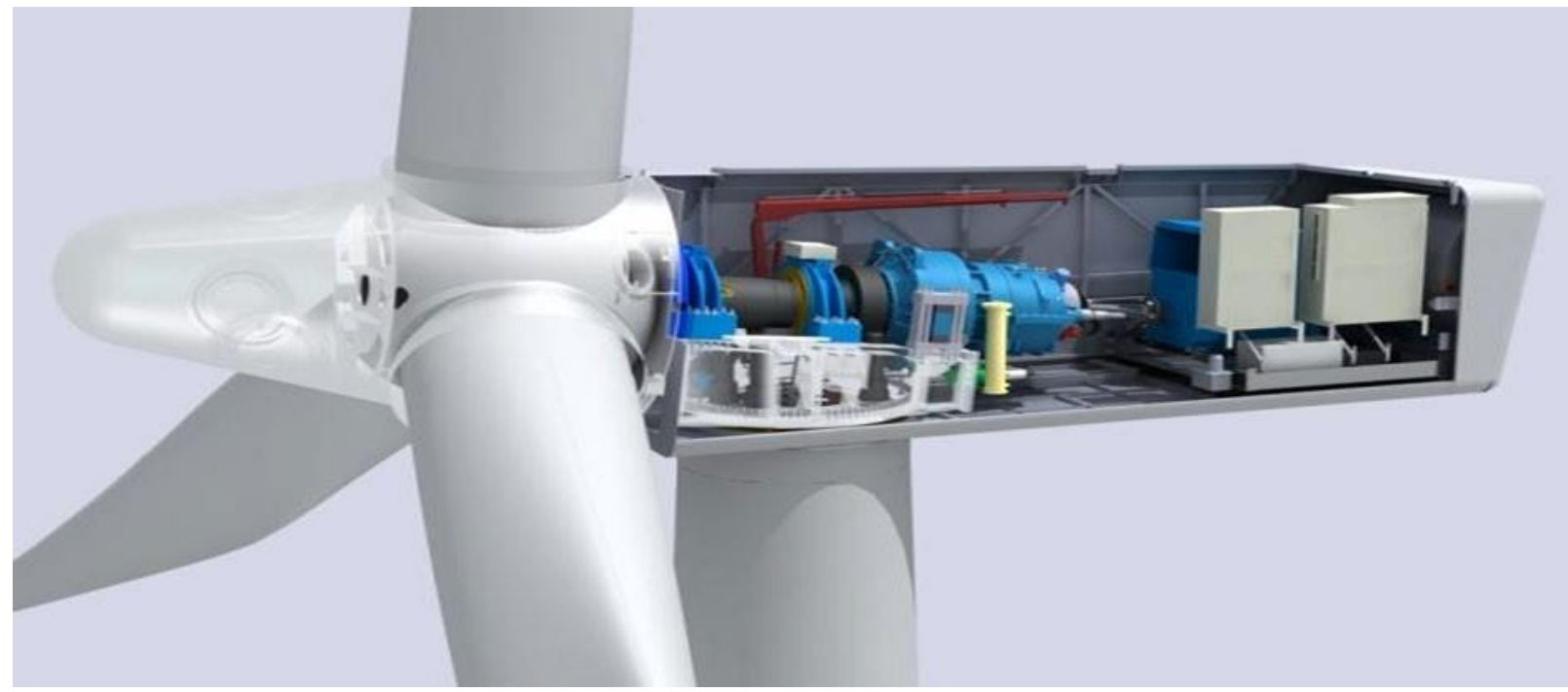

Şekil 3.1. Rüzgar türbini bileşenleri görünümü 


\subsection{Türbin Özellikleri}

$\mathrm{Bu}$ çalışmada örnek olarak seçilen rüzgar enerji santralinde kullanılan türbinler 2,3 MW'l1k rüzgar türbini olup, türbini karakterize eden temel parametreler aşağıdaki gibidir.

Türbin Sınıfi

Kule Yüksekliği

Rotor Çap1

Kanat Uzunluğu

Süpürdüğü Alan

Rotor Hiz1

Kanat A

Rotor Ağırlığ

Nacelle (motor yeri)

Kule Ağırlığ

Jeneratör

Çıkış Gücü

Voltaj

Y1llık $8 \mathrm{~m} / \mathrm{s}$ de

Güç Ayarı

Devreye Girme Hizı

Nominal Güç İçin

Devreden Çıkma Hızı

Maksimum 3s Ani Rüzgar
: III $(7,5 \mathrm{~m} / \mathrm{s})$

: $80 \mathrm{~m}$

: $101 \mathrm{~m}$

: $49 \mathrm{~m}$

: $8000 \mathrm{~m}^{2}$

: $6-16 \mathrm{dev} / \mathrm{dk}$

$: 10,9 \mathrm{t}$

$: 62 \mathrm{t}$

$: 82 \mathrm{t}$

: $162 \mathrm{t}$

: Asenkron

: 2,3 MW

: $690 \mathrm{~V}$

: 9,500 MWh

: Kanat açısını değiştirerek.

: $3-4 \mathrm{~m} / \mathrm{s}$

: $12-13 \mathrm{~m} / \mathrm{s}$

$: 25 \mathrm{~m} / \mathrm{s}$

: $60 \mathrm{~m} / \mathrm{s}$ (IEC verisyonu)

\subsection{Rüzgar Gülü Haritası}

Bu çalışmada örnek olarak seçilen bölgenin 2012-2018 yılları arası için hakim rüzgar yönünü ve baskın yönlere göre aktif güç değişimini gösteren ve Wind Rose yazılımı kullanılarak oluşturulan rüzgar gülü Şekil 3.2'de verilmiştir. Sekil 3.2'den hakim rüzgar yönünün ve baskın aktif gücün $15^{\circ}$ - $30^{\circ}$ arasında ve kuzeydoğu yönünde odaklandığı söylenebilir. Yıl içerisinde diğer yönlerde de rüzgar esmesi ve aktif güç üretiminin gerçekleştiği de görülmektedir.

\subsubsection{Rüzgar Gücü}

Rüzgar olarak adlandırılan ve v hızıyla hareket eden $\mathrm{m}$ hava kütlesinin taşıdığı hareket (kinetik) enerjisi, kinetik enerjinin bilinen temel tanımından,

$$
E_{k}=\frac{1}{2} m v^{2}
$$

olarak yazılır. Bu hava kütlesi (yani rüzgar) hub (göbek) yüksekliğine sahip rüzgar türbininin L kalınlığında, r yarıçapında ve özel eğime sahip kanatlarına çarptığında kanatlar dönerek iş (W) yapar ve elektrik enerjisi (E) üretilir. Kanatların tam bir tur dönmesi ile kanatlar alanı süpürür.

$A=\pi r^{2}$ 


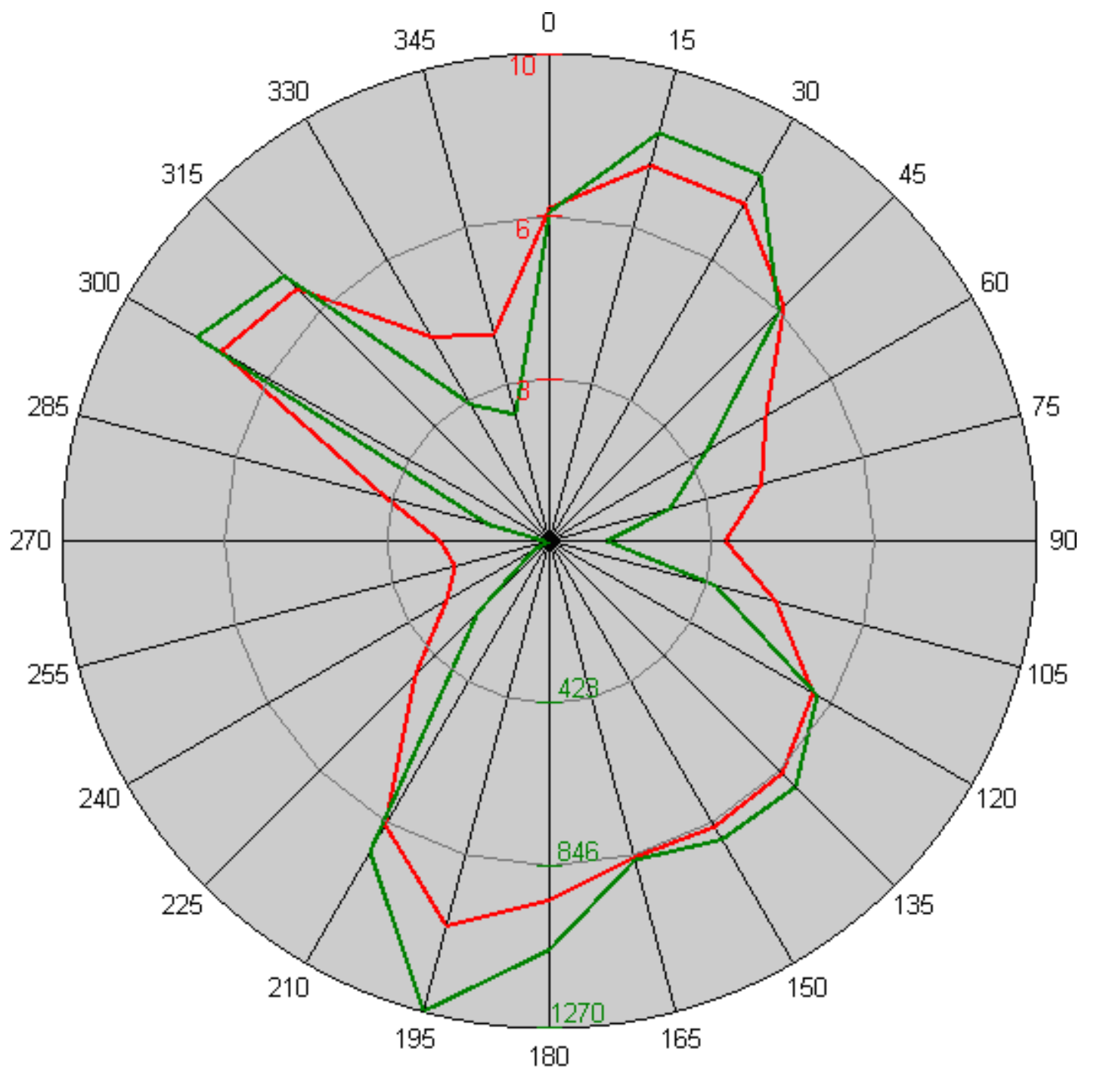

\section{AKTiF GÜç $(\mathrm{kW})$}

RÜZGAR HIZI (m/s)

Şekil 3.2. Çanakkale ili Ezine ilçesinde bulunan bir rüzgar santrali için, 2012 - 2018 yılları arası, rüzgar hızı ve aktif güç değerlerini içeren rüzgar gülü

$\rho\left(\rho_{\text {ort }}=1,225 \mathrm{~kg} / \mathrm{m}^{3}\right)$ yoğunluğuna sahip hava kütlesinin taşıdığı enerjinin rüzgar türbinine aktardığı teorik güç $\mathrm{P}_{\mathrm{T}}$ ise, birim zamanda yapılan iş ya da harcanan veya üretilen enerji olarak ifade edilen güç tanımından,

$$
P_{T}=\left\{\begin{array}{l}
\frac{W}{t}=\frac{F \cdot s}{t}=F \cdot v \quad, \quad \frac{s}{t}=v \\
\frac{E_{k}}{t}=\frac{\frac{1}{2} m v^{2}}{t}
\end{array}\right.
$$

olarak yazılır. (4) denkleminden de görüleceği üzere; rüzgar olarak adlandırılan v hızına sahip hava kütlesi rüzgar türbinine çarptığında $\mathrm{t}$ sürede $\mathrm{L}(=\mathrm{v} \times \mathrm{t})$ kalınlığındaki kanadı geçerek, eğimli 
kanadın dönmesini ve A alanını süpürmesini sağlar. Böylece kanat tam bir tur attığında $\mathrm{V}$ (A x L) hacmi oluşur ve bu hacim içerisindeki v hızına sahip $\mathrm{m}(=\rho \times \mathrm{V})$ hava kütlesi;

$P_{T}=\frac{E_{k}}{t}=\frac{\frac{1}{2} m v^{2}}{t}=\frac{\frac{1}{2} \rho V v^{2}}{t}=\frac{\frac{1}{2} \rho A L v^{3}}{t}=\frac{\frac{1}{2} \rho \cdot \pi r^{2} \cdot v t \cdot v^{2}}{t}=\frac{1}{2} \rho \pi r^{2} v^{3}$

teorik gücü türbine aktarır. Çeşitli kayıplar göz önüne alındığında; pratikte tüm güç aktarılamaz. Bu nedenle (5) denklemine Betz limiti (Betz, 1966; Burton, ve ark., 2001) olarak adlandırılan ve $C_{p}$ olarak gösterilen güç aktarım kat sayısı (Betz limitine göre $C_{p} \leq 0,5926$ ) çarpan olarak eklenir. Böylece (5) denklemi,

$$
P_{R}=\frac{1}{2} C_{p} \rho \pi r^{2} v^{3}
$$

halini alır ve bu ifade reel güç $\left(\mathrm{P}_{\mathrm{R}}=\mathrm{C}_{\mathrm{p}} \times \mathrm{P}_{\mathrm{T}}\right)$ olarak adlandırılır. (6) ile verilen reel güç denkleminden görüleceği üzere rüzgardan elde edilecek gücün; rüzgar hızının küpü, kanatların süpürdüğü alan ve hava yoğunluğu ile doğru orantılı olduğu görülmektedir. Buradan; bir rüzgar türbininde rüzgar hızının, kanatların süpürdüğü alanın ve hava yoğunluğunun, kapasite faktörünü etkilediği söylenebilir.

\subsection{Betz Limiti ve Verim}

Türbin kanatlarına gelen rüzgarın, giriş ve çıkış hızları arasındaki değer farkına bağlı olarak gücünde bir değişim oluşmaktadır. Betz (Betz, 1966) teorisine göre, günümüz teknolojisi göz önüne alındığında, teorik olarak rüzgar türbinin enerji veriminin en fazla \%59,26 olacağını ifade edilmektedir (Betz, 1966; Burton, et al., 2001). Bu durumda v hızında $P_{R}$ gücünü üreten bir rüzgar türbinin enerji verimi;

$$
\text { Verim }=C_{p}=P_{P_{T}}=\frac{\text { Yilda Üretilen Toplam Enerji }}{P_{T} .8760}
$$

olarak yazılır (Çetin, 2010).

\subsection{Weibull ve Rayleigh Rüzgar Dağılım Ĕgrileri}

Rüzgar hızının dağılım durumunun belirlenmesinde birkaç farklı yöntem kullanılmaktadır. Bu yöntemlerden en çok kullanılanları Weibull dağılımı ve Rayleigh dağılımıdır (Çetin ve ark., 2011). Bu çalışmada örnek olarak seçilen RES sahasının rüzgar verileri Çizelge 3.1'de, bu verilere göre; sahanın rüzgar esme sıklığı ile Weibull ve Rayleigh dağılımları Şekil 3.3'te verilmiştir.

Çizelge 3.1. Santral sahasının rüzgar verileri ve hata payı

\begin{tabular}{|c|c|c|c|c|}
\hline $\begin{array}{c}\text { Ortalama rüzgar } \\
\text { hız1 }\end{array}$ & $\begin{array}{c}\text { Maksimum } \\
\text { rüzgar hız1 }\end{array}$ & $\begin{array}{c}\text { Minimum } \\
\text { rüzgar hız1 }\end{array}$ & Standart sapma & Hata pay1 \\
\hline 6,14 & 23,20 & 0,01 & 3,60 & 1,57 \\
\hline
\end{tabular}




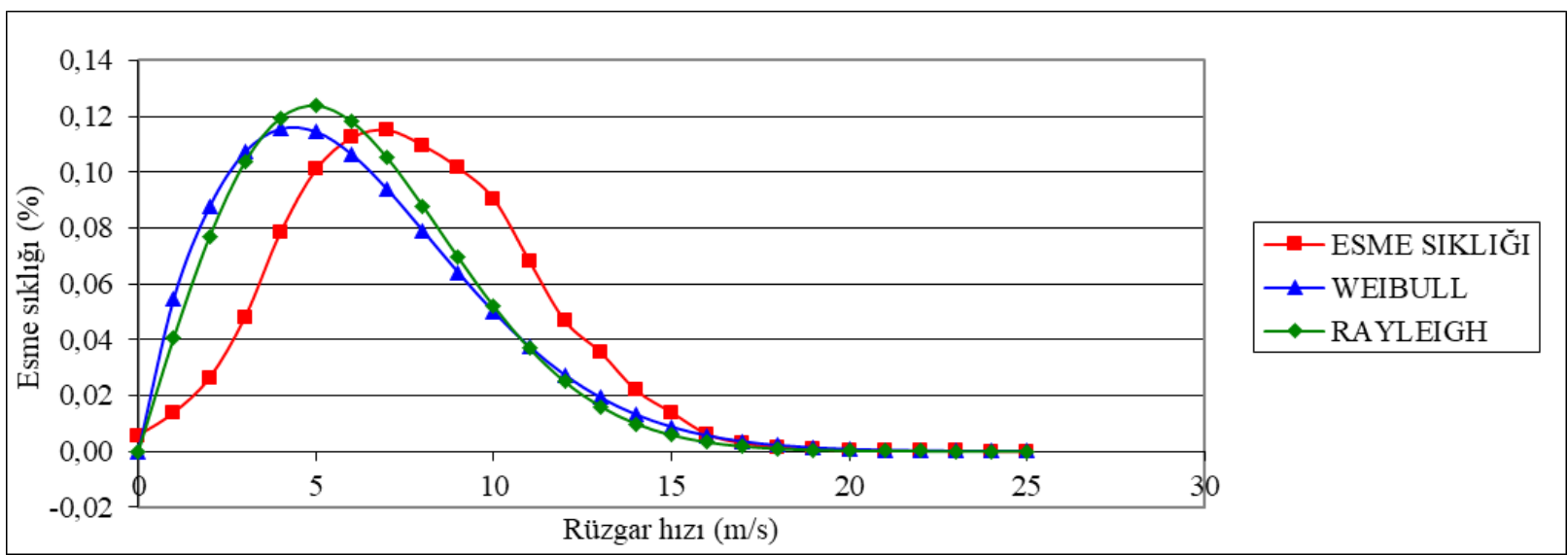

Şekil 3.3 Sahanın 2018 yılı rüzgar esme sıklığı ile Weibull ve Rayleigh dağılımları

\subsection{Santral Verilerinin İncelenmesi}

\subsubsection{Meteorolojik Verileri}

Çalışmada ele alınan rüzgar enerjisi üretim sahasına ait 2012-2017 yılları için aylık ortalama rüzgar hız verileri Çizelge 3.2'de yıllık rüzgar hız ortalamaları dağılımı Şekil 3.4'te listelenmiştir.

Çizelge 3.2. Santral sahasına ait ortalama rüzgar hız değerleri

\begin{tabular}{|c|c|c|c|c|c|c|c|c|c|c|c|c|c|}
\hline Y11/Ay & 01 & 02 & 03 & 04 & 05 & 06 & 07 & 08 & 09 & 10 & 11 & 12 & Ort. \\
\hline 2012 & 6,92 & 7,63 & 6,40 & 8,16 & 7,29 & 4,78 & 8,13 & 7,38 & 8,15 & 5,78 & 8,51 & 7,42 & 7,21 \\
\hline 2013 & 9,38 & 7,08 & 7,72 & 6,81 & 6,41 & 5,67 & 7,76 & 8,96 & 6,27 & 5,86 & 6,90 & 6,24 & 7,09 \\
\hline 2014 & 7,10 & 6,99 & 6,95 & 6,05 & 7,01 & 5,67 & 6,18 & 5,51 & 6,26 & 7,13 & 6,61 & 5,54 & 6,42 \\
\hline 2015 & 7,17 & 9,79 & 6,94 & 6,56 & 6,37 & 6,38 & 6,40 & 7,39 & 6,73 & 6,23 & 7,42 & 6,15 & 7,04 \\
\hline 2016 & 8,49 & 7,94 & 7,62 & 5,52 & 5,89 & 5,72 & 7,60 & 8,23 & 8,15 & 6,08 & 7,47 & 7,56 & 7,19 \\
\hline 2017 & 7,89 & 8,40 & 6,37 & 6,32 & 5,62 & 6,18 & 6,02 & 7,20 & 7,58 & 6,85 & 7,93 & 7,25 & 6,97 \\
\hline
\end{tabular}

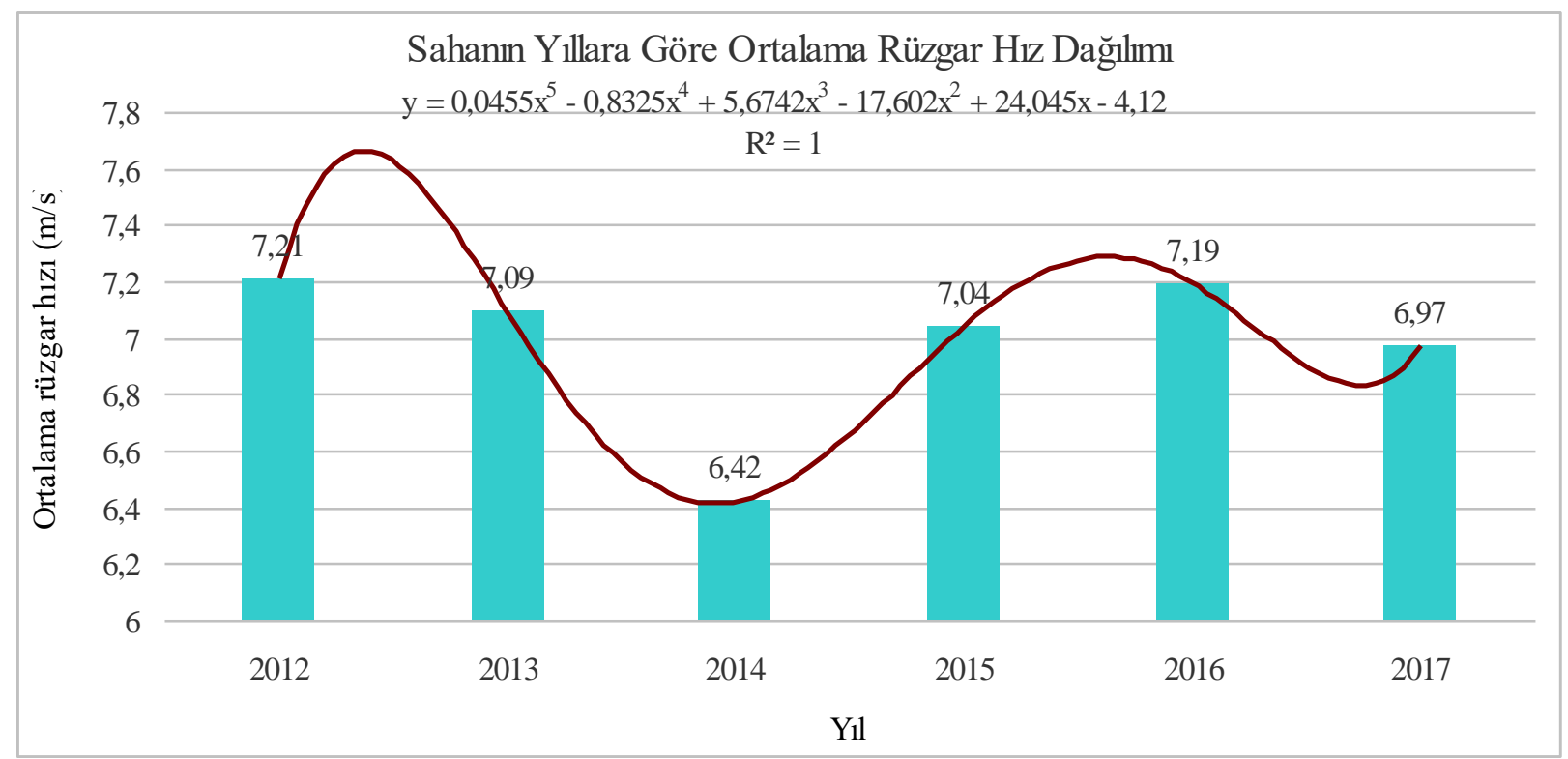

Şekil 3.4. Sahanın yıllara göre ortalama rüzgar hız dağılımı 


\subsubsection{Santral Yıllık Üretim Verilerine Göre Değerlendirmeler}

Çalışmada örnek olarak alınan Çanakkale Güney bölgesi rüzgar enerji santralının 2012-2018 yılları arasında oluşan elektrik üretim değerleri dikkate alınarak (Anonim, 2019b), santralın kurulu gücüne göre, yıllık kapasite faktörleri hesaplanmış ve değerler Çizelge 3.3'de verilmiştir. Elde edilen verilere göre 2012-2018 y1llarına ait kapasite faktörü 2014 yılına karşılık gelen \%27,3 ile 2012 yılına karşılık gelen \%32,7 arasında değişmekte olup ortalama değer \%30,7 olarak gerçekleşmektedir. Bu çalışmada yıllık üretim üzerinden gidilip, emre amadeliği (availability) ve türbin bazlı santral performansını etkilemeyen, mücbir ve türbin bazlı olmayan duruşlar dan kaynaklanan kayıplar kapasite faktörü çalışmasına dahil edilmemiştir. Çalışmada santralın bulunduğu bölgenin, ortalama rüzgar tahmin bilgileri ile, santralın yıllık rüzgar teknik enerji potansiyeli, Betz limitine göre üretilebilecek maksimum enerji potansiyeli ve gerçekleşen üretim değerlerine dair hesaplamaları yapılarak Çizelge 3.4'de verilmiştir.

Çizelge 3.3. Santralın üretim ve kapasite faktörü incelemesi (Anonim, 2019b)

\begin{tabular}{|c|c|c|c|}
\hline Y11 & $\begin{array}{c}\text { Santral Kurulu } \\
\text { Gücü (MW) }\end{array}$ & $\begin{array}{c}\text { Y1llik Üretim } \\
(\mathrm{MW})\end{array}$ & $\begin{array}{c}\text { Kapasite Faktörü } \\
(\%)\end{array}$ \\
\hline 2012 & 29,9 & $85.457,73$ & 32,66 \\
\hline 2013 & 29,9 & $79.191,53$ & 30,23 \\
\hline 2014 & 29,9 & $71.449,01$ & 27,27 \\
\hline 2015 & 29,9 & $84.009,31$ & 32,07 \\
\hline 2016 & 29,9 & $84.393,81$ & 32,22 \\
\hline 2017 & 29,9 & $78.379,99$ & 29,93 \\
\hline 2018 & 29,9 & $79.487,10$ & 30,34 \\
\hline
\end{tabular}

Çizelge 3.4. Santral sahasının, rüzgar enerji potansiyeli ve Betz teorisine göre enerji tahmini

\begin{tabular}{|c|c|c|c|}
\hline Y1l & $\begin{array}{c}\text { Rüzgar Verilerine Göre Teknik } \\
\text { Enerji Potansiyeli (MWh) }\end{array}$ & $\begin{array}{c}\text { Betz Limitine Göre } \\
\text { Üretilebilecek Enerji } \\
\text { Potansiyeli (MWh) }\end{array}$ & $\begin{array}{c}\text { Gercekleşen Üretim } \\
\text { (MWh) }\end{array}$ \\
\hline 2012 & $223.682,34$ & $131.972,58$ & $85.457,72$ \\
\hline 2013 & $215.712,21$ & $127.270,20$ & $79.191,52$ \\
\hline 2014 & $152.194,64$ & $897.94,83$ & $71.449,00$ \\
\hline 2015 & $209.341,88$ & $123.511,71$ & $84.009,30$ \\
\hline 2016 & $221.235,64$ & $130.529,02$ & $84.393,80$ \\
\hline 2017 & $198.373,55$ & $117.040,39$ & $78.379,99$ \\
\hline 2018 & $197.525,87$ & $116.540,26$ & $79.487,10$ \\
\hline
\end{tabular}

Çizelge 3.5. Santral sahasının verim incelemesi

\begin{tabular}{|c|c|c|c|c|}
\hline Y1lı & $\begin{array}{c}\text { Rüzgar Verilerine } \\
\text { Göre Teknik Enerji } \\
\text { Potansiyeli (MWh) }\end{array}$ & $\begin{array}{c}\text { Gercekleşen } \\
\text { Üretim } \\
(\mathrm{MWh})\end{array}$ & $\begin{array}{c}\text { Rüzgar Enerji } \\
\text { Potansiyeline } \\
\text { Göre Ürteim } \\
\text { Verimi }(\%)\end{array}$ & $\begin{array}{c}\text { Betz Limitine } \\
\text { Göre Bağıl } \\
\text { Verim (\%) }\end{array}$ \\
\hline 2012 & $223.682,34$ & $85.457,72$ & 38,20 & 64,75 \\
\hline 2013 & $215.712,21$ & $79.191,52$ & 36,71 & 62,22 \\
\hline 2014 & $152.194,64$ & $71.449,00$ & 46,95 & 79,57 \\
\hline 2015 & $209.341,88$ & $84.009,30$ & 40,13 & 68,02 \\
\hline 2016 & $221.235,64$ & $84.393,80$ & 38,15 & 64,66 \\
\hline 2017 & $198.373,55$ & $78.379,99$ & 39,51 & 66,97 \\
\hline 2018 & $197.525,87$ & $79.487,10$ & 40,24 & 68,21 \\
\hline
\end{tabular}


Santralın geçmiş yıllara ait rüzgar verilerine göre, 2012-2018 yılları arası için rüzgar enerji potansiyeline göre üretim verimi ve bu verimin Betz limitine göre bağıl verimi Çizelge 3.5'te verilmiştir.

\subsection{Kapasite Faktörü Değişiminin Olası Sebepleri}

Çizelge 3.3, Çizelge 3.4 ve Çizelge 3.5 'te verilen verilerin değerlendirilmesinden de görüleceği üzere kapasite faktörü yıllara göre değişmektedir. Bu değişimlerin olası sebepleri aşağıdaki şekilde özetlenebilir:

- $\quad$ Yllara göre oluşan değişik rüzgar rejimleri (mevsimsel değişmeler).

- $\quad$ Makinelerin devreye girme ve devreden çıkma rüzgar hızı limitleri (cut in, cut out).

- $\quad$ Bölgeye göre seçilen türbin sınıflarının iyi tespit edilmesi.

- $\quad$ Türbinlerin bakım planlarının, rüzgar tahminine göre iyi hesaplanamaması.

- $\quad$ Türbin arıza durumları (emre amadelik).

- $\quad$ Kanatlarda ki mekanik enerjiyi, elektrik enerjisine dönüştüren ara elamanların, dişli kutusu (gearbox) vb. gibi yıpranma zamanları.

- $\quad$ Arızanın çabuk veya uzun sürede giderilmesi (yetişmiş teknik elaman)

$\mathrm{Bu}$ konularda yapılacak en iyi iş; planlamaların ve hesaplamaların işin en başında en iyi şekilde yapılması, olası tüm durumların irdelenerek dikkate alınması ve alanında uzman, deneyimli, yeterli sayıda teknik personel ile yedek parça temini ve hızlı müdahale ekiplerinin oluşturulması, ekiplerin belli aralıklarda eğitimlerinin geliştirilmesi gibi faktörler, kapasite faktörünün artışına ve dolayısı ile elektrik enerjisini üretiminin artırılmasına katkılar sağlayacaktır.

\subsection{Rüzgar Türbini Çevirme Oranı ve Kapasite Kullanımı}

Şekil 3.5 ve Şekil 3.6'da bir rüzgar türbinin kanatlarına gelen rüzgar enerjisinin önce mekanik enerjiye daha sonra da elektrik enerjisine dönüştürülerek, iletim hatlarına aktarılmasına kadar gecen evreleri, her bir evredeki olası enerji kayıplarını ve kapasite kayıplarının ne oranda olacağını teorik olarak göstermektedir (Ata, 2008; Switzer, 2009).

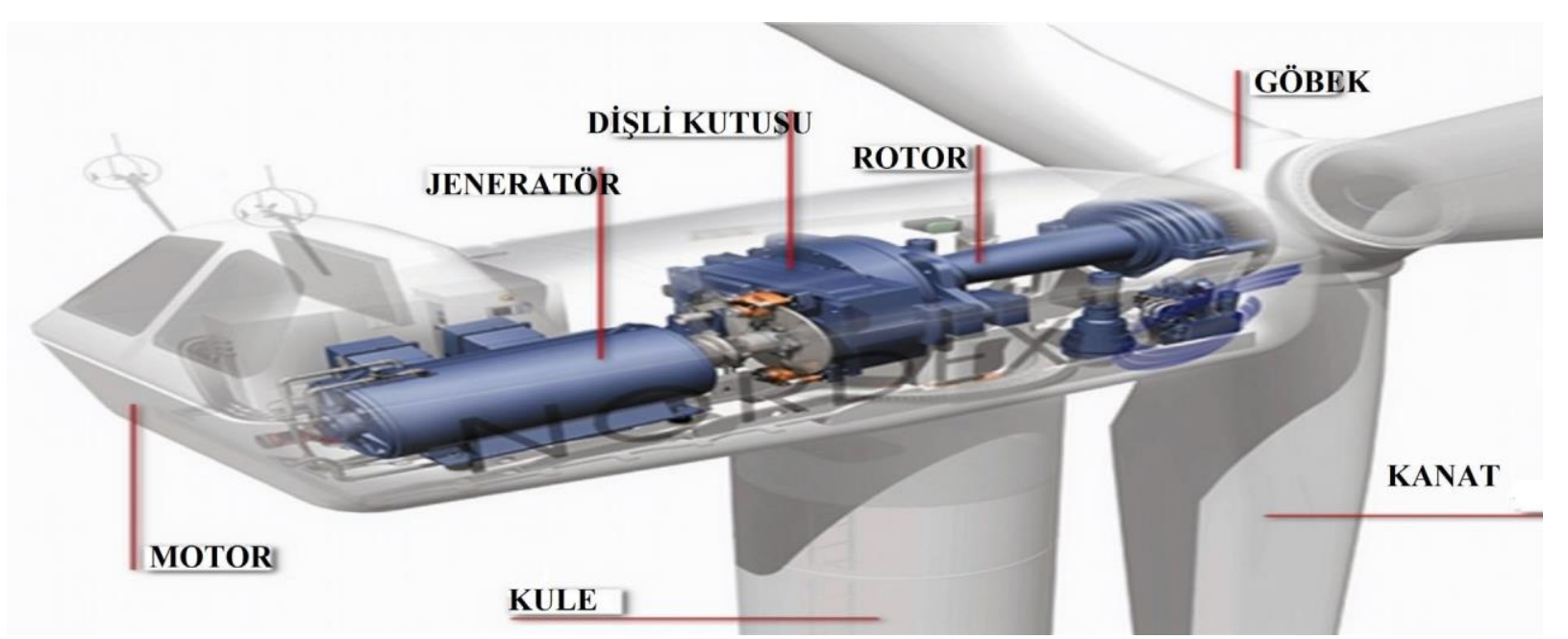

Şekil 3.5. Türbin içi enerji kaybı yaşanan bileşenlerin görünümü (Anonim, 2019f'den uyarlanmıştır) 
Örneğin; $3.046 \mathrm{~kW}$ olarak kanatlara gelen teknik potansiyel güç, öncelikle $1.340 \mathrm{~kW}$ değerinde rotora hareket enerjisi olarak aktarılmaktadır. Daha sonra Betz limitine göre bu oran en çok 0,5926 $(\% 59,26)$ olabilmektedir. Bu değer teorik hesaplamalarda üst limit olarak kabul edilmektedir. Şekil 3.6'da verilen ve örnek olarak ele alınan türbin sistemi için bu değer 0,44 olarak görülmektedir.

Rotor milinin oturduğu yataklarda verim 0,996 dır. Buradan da yataklarda değer 1.335 kW'a düşmektedir. Gearbox olarak adlandırılan ve düşük hızı yüksek hızlara döndüren dişli kutusunun verimi 0,972 civarında olmaktadır. Bu aşamada 0,028 'lük bir kapasite kaybı meydana gelmekte olup güç yaklaşık $1.297 \mathrm{~kW}$ 'a düşmektedir. Mekanik hareket enerjisini elektrik enerjisine dönüştüren jeneratör verimi ise 0,965 'tir. Sonuç olarak $3.046 \mathrm{~kW}$ olarak türbin kanatlarına gelen rüzgar enerji gücü jeneratörden $1.252 \mathrm{~kW}$ olarak elektrik enerjisine dönüşmektedir.

Rüzgar türbin jeneratörlerinde elde edilen elektrik enerjisinin frekansı sabit $50 \mathrm{~Hz}$ şebekelere uyumlu değildir. Rüzgar hızının değişkenliği sebebi ile jeneratör kutuplarında oluşan frekans farkl11ıklar göstermektedir.

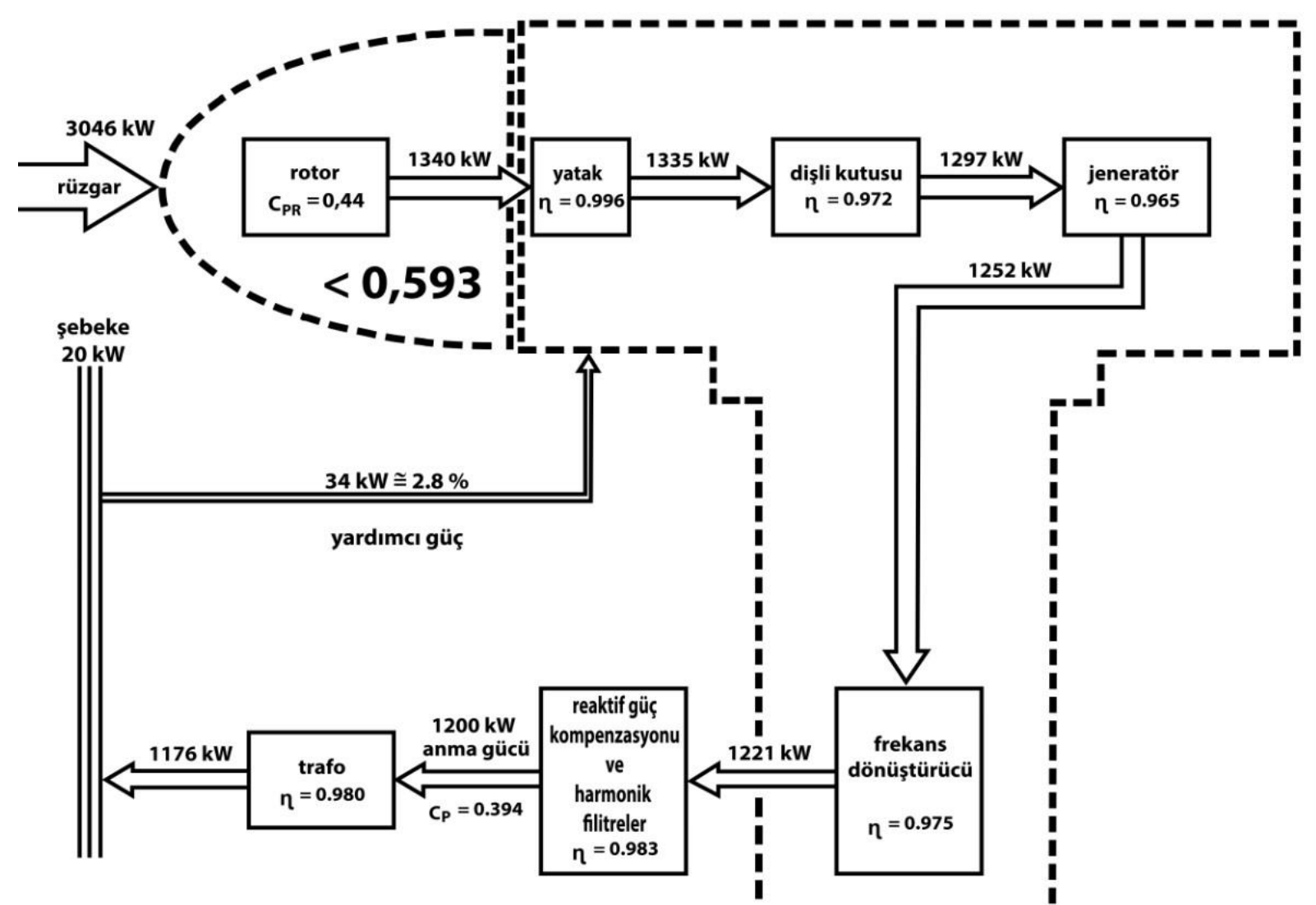

Şekil 3.6. Türbin içi kapasite kaybı yaşanan bileşenler ve olası verimleri (Switzer, 2009'dan uyarlanmıştır)

$\mathrm{Bu}$ şekilde enterkonnekte şebekeye bağlantı yapılamamaktadır. Konvertör dediğimiz frekans çeviriciler, frekansı farklı olan elektrik enerjisini ilk önce DC sabit gerilime dönüştürür. Diğer bir konvertörde DC geriliminin frekansı $50 \mathrm{~Hz}$ 'e ayarlanmış ulusal şebekeye uyumlu alternatif gerilime dönüştürür. Bu konvertörler de çıkışı güç $1.221 \mathrm{~kW}$ olur. Ayrıca; harmonik filtreleme sonucunda çıkış gücü $1.200 \mathrm{~kW}$ 'a düşer. 
Buraya kadar olan güç kayıplarına bakıldığında kanatların önünde bulunan 3.046 kW'lık güç 1.200 kW'a kadar düşer. Burada kantlardaki kayıplar dahil, rüzgar türbin kapasite kullanım oranı, yani kapasite faktörü 0,394 olur.

Öte yandan çıkış gerilimi düşük olduğu için iletim hatlarına aktarılması gereken gerilimin yükseltilmesi gerekmektedir. Çıkış gerilimini yükseltmek için kullanılan trafo verimi ise 0,98 olduğunda, şebekeye aktarılan güç $1.176 \mathrm{~kW}$ olacaktır. Elektrik üretim sayaçlarında yazılan ve satışa esas güç ise $1.176 \mathrm{~kW}$ olarak gerçekleşir ve var olan potansiyel gücün ancak $(1.176 / 3.046=$ 0,38) \%38 çevirme kapasitesi ile aktarılmış olur. Dolayısı ile \%44 olarak kanatlara alınan güç trafo çıkış1 \%38 olarak gerçekleşir. Bu aşamalar sırasında oluşan \%6'lık kayıp rüzgar türbininin bileşenlerinde kaybolmuştur.

Yeni nesil türbin çalışmalarında doğrudan sürüş (direct drive) olarak adlandırılan türbinlerde, aradaki dişli kutusu (gearbox) kaldırılarak, aradaki kapasite kayıplarını minimize edilmesi sonucu, türbin veriminin artırılması çalışmaları yapılmaktadır. Bu da kapasite faktörünü olumlu yönde etkilemektedir.

\section{Sonuç}

Çanakkale güney bölgesinde kurulu olan örnek bir rüzgar elektrik santralında yapılan incelemede farklı y1llarda \%25 ile \%35 (\%30 \pm 5$)$ arasında değişen kapasite faktörleri değişimleri hesaplanmıştır. Bölgenin rüzgar rejimi yanında hava sıcaklığı, hava yoğunluğu ve basınç gibi diğer meteorolojik parametrelerin değişikliği ile bağlantılı olarak tek yıla bakıp ona göre yatırım yapmak yanıltıcı olabilmektedir. 2014 yılı kapasite faktörlerine bakılması durumunda, yatırımın daha geç geri dönüşüm sağlayacağı belirlenebilirdi. Fakat diğer yıllardaki kapasite faktörleri incelendiğinde, Avrupa ortalaması olan \%32 değerinin yakalanmış olduğu gözlemlenmektedir. Bu durumda bir kaç yılın ortalamasına bakmak daha az yanıltıcı olmakla beraber, daha isabetli kararlar vermede yardımcı olmaktadır.

Rüzgar türbin sahalarından beklentiler; yatırım maliyetlerinin minimum sürede geri kazanıp, üretilen enerjinin optimum şekilde kâra dönüştürülmesidir. Bu nedenle; öncelikle, seçilen sahanın rüzgar parametreleri ve teknik potansiyeli ile birlikte, RES santralinin emre amadeliği yanında türbin verimi ilişkisi de önem taşımaktadır.

İkinci olarak; rüzgar teknik potansiyelinin yanında, o bölgede kullanılacak türbin sınıfı incelemesinde, var olan kapasitenin ne kadarının elektrik enerjisine dönüştürülüp, hangi sınıf türbin seçiminin kapasite faktörünü arttıracağı ve kapasitenin optimum kullanılabileceği hesabı iyi yapilmalidir.

Saha kapasite faktörünü etkileyen diğer bir kriter, emre amade durumu, türbin arıza ve bakım zaman planlamasıdır. Örnek olarak, \%93 emre amade sağlayacağını taahhüt eden bir türbini ele aldığımızda, seçtiğimiz bölgenin teknik potansiyel kapasitesinden \%7’lik bir zaman diliminden faydalanılmayacanı ifade eder.

Yatırım yapılacak saha yerlerinin iyi seçilmesi ve tespit edilen sahaların kapasite faktörlerinin net ve en doğru şekilde hesaplanıp çıkartılması, hangi sınıf rüzgar türbini kurulumunun yapılması gerektiği, maliyetlerin geri dönüşümü ve en verimli şekilde üretimin gerçekleşmesi 
anlamını taşımaktadır. Sonuç olarak; yenilenebilir enerjiden üretilecek elektrik, dışa bağımlı fosil yakıt kullanımını azaltacaktır. Bu da ülkemizin dışa gidecek enerji harcamalarını kısması ve ülkede kalacak olan paranın ülke içinde ekonomiye olan katkısını artırarak, ülke vatandaşlarının refah artışında kullanılması anlamını ifade etmektedir.

Çanakkale Bölgesi’nin deniz kıyılarındaki pürüzsüzlük oranının düşüklüğü ve teknik potansiyel kapasite faktörünün yeterliliği nedeniyle denizsel (Off-Shore) rüzgar türbin sahası olarak değerlendirilmesi, yenilenebilir enerji üretime olan katkısını olumlu yönde artıracağı öngörülmektedir. Bu yönüyle de Çanakkale bölgesinin dikkate değer potansiyele sahip olduğu ifade edilebilir.

Çanakkale bölgesinin teorik rüzgar potansiyeli 13.013 MW ile Türkiye illeri arasında Balıkesir ilinden sonra ikinci sırada yer almaktadır (Anonim, 2019d). Devreye alınan ve halihazırda aktif olarak çalışan 12 santralin toplam kurulu gücü göz önüne alındığında, teorik potansiyelin yaklaşık \%2,5'i kullanılabilmektedir. Tüm santral türleri dikkate alındığında; 20'si lisanslı ve 5'i lisansız olmak üzere aktif santral sayısı 25 olan Çanakkale ili 3.064 MW kurulu gücü ile 21.107 GWh yıllık elektrik üretimi yapmaktadır (Anonim, 2019a). Bu değerleri ile Çanakkale ili Türkiye'nin kurulu güce oranı $\% 4,87$ ve tüketime oranı ise $\% 8,26$ olarak gerçekleşmektedir. İşletmedeki RES santralleri bazında bakıldığında Çanakkale \%4,8 ile 5. sıradadır. İnşa halindeki RES'ler göz önüne alındığında Çanakkale 203,4 MW (\%33,55) değeri ile 1. sırada yer almaktadır (Anonim, 2019g).

Sonuç olarak; teknik kapasite potansiyeli, kapasite faktörü ve yeni yatırım alanlarının uygunluğu dikkate alındığında Çanakkale bölgesi yenilenebilir enerji kaynaklarından rüzgar enerji potansiyeli bakımından yatırım cazibesi ilk üç sıralarda olma konumunu sürdürmektedir.

\section{Teşekkür}

Yazarlar, bu projeye desteklerinden dolayı Enerjisa Üretim'e teşekkürlerini sunmaktadır. Bu çalışma aynı zamanda Yüksek Lisans Tez Çalışması olan "Çanakkale'de Rüzgar Enerji Santrallerinin Kapasite Faktörlerinin Araştırılması Çalışması’nın bir kısmıdır. 


\section{Kaynakça}

Akkaş A.A., 2001. Rüzgar Enerjisi Sistemleri Performans Değerlendirmesi, Rüzgar Enerji Sempozyumu, 5-7 Nisan 2001. 25 Şubat 2019, http://www.ruzgarsempozyumu.org/wpcontent/uploads/2014/08/008.pdf

Akpınar E.K., ve Akpınar S., 2004. "Determination of the wind energy potential for Maden-

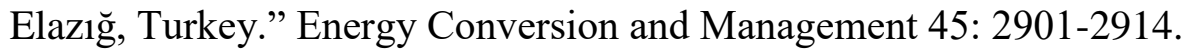

Anonim, 2019a. 23 Şubat 2019, https://www.enerjiatlasi.com/sehir/canakkale/

Anonim, 2019b. 15 Şubat 2019, http://www.enerjiatlasi.com/ruzgar/canakkaleruzgar-santrali.html

Anonim, 2019c. 25 Şubat 2019 https://www.gmka.gov.tr/dokumanlar/yayinlar/CanakkaleEnerji-Yatirim-Rehberi.pdf

Anonim, 2019d. 25 Şubat 2019, https://www.enerjiatlasi.com/ruzgar-enerjisi-haritasi/turkiye Anonim, 2019e. 28.Şubat 2019, http://habitatdernegi.org/wp-content/uploads/Ruzgar_Enerjisi.pdf sayfa 15

Anonim, 2019f. 28 Şubat 2019. https://www.emagrup.com/tr/ruzgar-enerjisi

Anonim, 2019g. http://www.tureb.com.tr/yayinlar/turkiye-ruzgar-enerjisi-istatistik-raporuocak-20-1

Araslan O., 2010. "Technoeconomic analiysis of electric generation from wind energy in Kütahya Turkey" Energy, 35, 120-131.

Ata R., 2008. Gazi Üniv. Müh. Mim. Fak. Der., 23 (3): 523-529.

Ay A., 2016. Hava Yoğunluğunun Rüzgar Türbinleri Güç Eğrisi Üzerindeki Etkisi. 25 Şubat 2019. https://www.elektrikport.com/teknik-kutuphane/hava-yogunlugununruzgar-turbinleri-guc-egrisi-uzerindeki-etkisi/18579\#ad-image-0

Betz A., 1966. "Introduction to the Theory of Flow Mechanics". Trans.: Randal, D.G., Oxford: Pergamon Press.

Bilgili M., Şahin B., ve Kahraman A., 2004. "Wind energy potential in Antakya and İskenderun regions Turkey.” Renewable Energy, 29: 1733-1745. 
Burton T., Sharpe D., Nick J., and Bossanyi E., 2001. Wind Energy Handbook. Jhon Wiley \& Sons Ltd., ISBN 047148997 2. England. 05 Nisan 2019. http://library.uniteddiversity.coop/Energy/Wind/Wind_Energy_Handbook.pdf

Çetin N. S., 2010. 'Rüzgar Türbini Üretim Teknolojileri ve Türkiye'de Kurulu Olan Büyük Güçlü Rüzgar Santrallerinin Kapasite Faktörleri”, Uluslararası Enerji Türk Zirvesi, 0204 Eylül 2010, İzmir-TÜRKIYYE

Çetin N. S., Çelik H., Başaran K., 2011. 16-18 May 2011, Rüzgar Türbinlerinde Kapasite Faktörü ve Türbin Sınıfi İlişkisi, sayfa 131, 6th International Advanced Technologies Symposium (LATS'11), 16-18 May 2011, Elazığg, Turkey. 25 Şubat 2019.

Eskin N., Artar H., ve Tolun S., 2008. "Wind energy potential of Gökçeada Island in Turkey." Renewable and Sustainable Energy Rewiews, 12: 839-851.

Güler Ö., 2009. “Wind energy status in electical energy production of Turkey,” Renewable and Sustainable Energy Rewiews, 13: 473-478.

Gökçek M., Erdem H. H., and Bayülken, A., 2007. Energy Exploration \& Exploition, 25 (6): 407-428.

Köse R., Ögür M.A., Erbağ O. ve Tuğcu A., 2004. "The Analiysis of wind data and wind energy potential in Kutahya", Turkey. Renewable and Sustainable Energy Rewiews, 8: 277-288.

Mathew S., 2006. "Wind Energy Fundemantals, resource Analysis and Economics, Springer Berlin Heidelberg Inc., Germany.

Özdamar A., Özbata N., Akın A., ve Yıldırım E. D., 2005. “An application of combined wind and solar energy system in İzmir." Renewable and Sustainable Energy Rewiews, 9: 624637.

Switzer E., 2009. Compon Lecture 4: October 24, 2009. 28 Şubat 2019. https://tr.scribd.com/document/309147702/HAU-E-Wind-Turbines-FundamentalsTechnologies-Application-Economics-2nd

Şenkal A., ve Çetin N.S., 2009. “Türkiye’de kurulu Olan Büyük Güçlü Rüzgar Santrallerinin Kapasite Faktörlerine Genel Bir Bakış”, Ege Bölgesi Enerji Formu, 12-13 Ekim 2009, Denizli. 
Şenlik İ., Çınar R., Çetin Ö., Efe Ç., Gençoğlu T., 2018. Güney Marmara Elektrik Enerjisi Raporu 2018, Güney Marmara Bölgesi Elektrik Enerjisi Çalışma Grubu, TMMOB Elektrik Mühendisleri Odası Bursa Şubesi, sayfa 24. 25 Şubat 2019, http://www.emo.org.tr/ekler/ac53d16b0e46456_ek.pdf

Uçar A., ve Balo F., 2009. "Investigetion of wind characteristic and assessment of wind generation potentiality in Uludağ-Bursa, Turkey." 86: 333-339. 